\section{HIV-testing among female sex workers on the border between Brazil and French Guiana: the need for targeted interventions}

\author{
Testes de HIV entre trabalhadoras do sexo \\ na fronteira entre Brasil e Guiana Francesa: a \\ necessidade de intervenções específicas
}

\section{La prueba del VIH en las trabajadoras sexuales en la frontera entre la Guyana Francesa y Brasil: la necesidad de intervenciones específicas}

\author{
Marie-Claire Parriault 1 \\ Astrid van Melle 1 \\ Célia Basurko 1 \\ Emilie Gaubert-Marechal 2 \\ Raimunda Hermelinda Maia Macena ${ }^{3}$ \\ Stéphanie Rogier 1 \\ Ligia Regina Franco Sansigolo Kerr 3 \\ Mathieu Nacher 1,2
}

1 Centre d'Investigation Clinique Antilles Guyane, Cayenne General Hospital, Cayenne, French Guiana. 2 COREVIH Guyane, Cayenne General Hospital, Cayenne, French Guiana.

3 Faculdade de Medicina Universidade Federal do Ceará, Fortaleza, Brasil.

Correspondence M.-C. Parriault

Centre d'Investigation Clinique Antilles Guyane, Cayenne General Hospital. 6 Avenue des Flamboyants, Cayenne / French Guiana 97300, France.

marie-claire.parriault@

ch-cayenne.fr

\begin{abstract}
The border between Brazil and French Guiana is a place of economic, cultural, social and sexual exchange. Female sex workers represent a high risk population for HIV in this area where sexual tourism is particularly developed. HIV testing seems to be an important element in the fight against the epidemic. Indeed, early HIV testing gives access to treatments and prevention. An HIVIAIDS knowledge, attitudes, behaviors and practices survey was conducted in 2011 among sex workers along the border between Brazil and French Guiana. A total of 213 female sex workers were interviewed. One third (31.5\%) of the interviewed had never tested for HIV. Factors associated with non HIV-testing were the lack of knowledge of places where to do an HIV test, to be 30 or older, feeling at risk of HIV, not evaluating one's own risk towards HIV, and living in Oiapoque. These results clearly suggest that targeted interventions are needed to encourage and assist female sex workers to get tested regularly.
\end{abstract}

Sex Workers; Border Areas; HIV

\section{Resumo}

A fronteira entre Guiana Francesa e Brasil é um lugar de intercâmbio econômico, cultural, social e sexual. Nessa área, onde o turismo sexual é particularmente desenvolvido, as mulheres profissionais do sexo representam uma população de alto risco de contágio pelo HIV. Os testes de HIV parecem ser um elemento importante da luta contra a epidemia. De fato, os primeiros testes de HIV dão acesso à prevenção e aos tratamentos. Foi realizada em 2011 uma pesquisa de conhecimento, atitudes, comportamentos e práticas sobre HIVIAIDS com mulheres profissionais do sexo ao longo da fronteira da Guiana Francesa com o Brasil. Foram entrevistadas 213 mulheres profissionais do sexo. Um terço (31,5\%) delas nunca tinha feito o teste de HIV. Fatores associados a não realização do teste de HIV foram: a falta de conhecimento dos locais onde fazer o teste, ter idade igual ou acima de 30 anos, sentir-se em risco de contágio pelo HIV, falta de avaliação do risco de contágio pelo HIV e habitante do Oiapoque. Esses resultados sugerem claramente que intervenções direcionadas às mulheres profissionais do sexo são necessárias para que os testes sejam feitos regularmente.

Profissionais do Sexo; Áreas de Fronteira; HIV 


\section{Introduction}

French Guiana and Brazil share a 730km-long border. Trade and exchanges between both sides of the Oyapock river are concentrated around two river towns: Oiapoque, on the Brazilian side (21,661 inhabitants in 2011), and Saint Georges de l'Oyapock (3,946 inhabitants in 2011), on the French side. Sex work is widely present in the area with numerous venues offering sexual services on the Brazilian side and customers coming from French Guiana. The area is also a supply and transit hub for illegal gold mining. Sex work is closely related to gold mining and many sex workers leave to work for a few months in isolated gold mines $1,2,3$.

In 2008, 43.5\% of women aged 15-64 in Northern Brazil had already performed an HIV test during their lifetime ${ }^{4}$. In 2011, 78\% of persons aged 15-69 years in French Guiana had performed an HIV test during their lifetime 5. The high incidence of AIDS in Northern Brazil, notably in the state of Amapa, has been a cause for concern. The North, one of Brazil's five regions, presents the second highest increase in HIV prevalence in the country ${ }^{6}$. AIDS incidence has declined in French Guiana over the past decade but remains the highest of all French territories (Institut National de Veille Sanitaire. http://www.invs.sante. fr/display/?doc=surveillance/vih-sida/BDD_sida/index.htm, accessed on 19/May/2014).

The epidemic both in Brazil and in French Guiana is described as a concentrated or mixed epidemic 7,8. Epidemics are concentrated if transmission occurs largely in defined vulnerable groups 9 , and mixed when the epidemic is defined by a prevalence in pregnant women that is consistently over $1 \%$, transitioning into the general population and raising concerns about the possibility of a generalized epidemic 9 .

The context of the border and the existing socioeconomic differences between the two sides of the border create a complex situation where the vulnerability of persons towards HIV can be increased 10,11. In 2011, the GDP per capita was 15,294 Euros in French Guiana 12 and 3,525 Euros (11,504 Brazilian Reals) in Amapá (Instituto Brasileiro de Geografia e Estatística. http://www. cidades.ibge.gov.br/xtras/temas.php?lang=\&cod mun $=160010 \&$ idtema $=125 \&$ search $=$ amapa, accessed on 10/Dec/2014). Sex workers are considered as an important driver of the HIV epidemic in the region and prevalence seems higher in this population $6,8,13$. In order to maximize the impact of prevention, the World Health Organization (WHO) and the Joint United Nations Programme on HIV/AIDS (UNAIDS) recommended in the second generation surveillance program to monitor high risk groups, among whom sex workers figure 14 .

Given the individual and collective benefits of highly active antiretroviral therapy, early HIV testing is the gateway to proper HIV care and treatment, and risk reduction 15,16,17.

The objectives of the present article were to describe the HIV testing practices among female sex workers in Oiapoque and Saint Georges de l'Oyapock and to identify predictive factors of HIV testing based on KABP (knowledge, attitudes, beliefs and practices) data collected in 2009-2010.

\section{Material and methods}

\section{Study design}

This is a cross-sectional survey performed among female sex workers aged 18 years and above, working on the border between Brazil and French Guiana and having had at least one paid intercourse in the past six months. Data collection took place over four months, in 2009-2010.

This study was conducted in partnership with the regional coordination for the fight against HIV, the Department of Community Health of the Federal University of Ceará and the following non-governmental organizations (NGOs): DAAC and Kikiwi network in French Guiana, and DPAC in Brazil.

\section{Sampling method}

Snowball sampling was used to select participants 18,19 . The principle was to find female sex workers, also referred to as "seeds", who have the desired characteristics and use their social networks to recruit similar participants. After initial seeds help to recruit respondents, the respondents then recruit others themselves, starting a process analogous to a snowball 19. Persons accepting to participate in the survey were interviewed by trained interviewers. Individual interviews were conducted confidentially faceto-face. The surveyors were all familiar with the field, originating from NGOs or from the community of sex workers. At the end of the interview, documentation of HIV prevention, NGO contacts, male and female condoms, and two food tickets in French Guiana or make-up in Oiapoque were given to the persons interviewed in order to compensate for the time spent answering the questionnaire. 


\section{Questionnaire}

An anonymous closed-ended questionnaire of 150 questions was applied to 35 sex workers in Saint-Georges-de-l'Oyapock and 178 in Oiapoque, the two main towns on the border.

It notably explored sociodemographic characteristics, sex work, intercourse with clients and non-clients, condom use, knowledge, attitudes, behaviors and practices regarding HIV, and STIs and stigma and discrimination towards HIVinfected persons. This questionnaire was constructed with NGOs working in the field, adapting behavioral surveillance survey questionnaires 20 . Nine questions specifically dealt with free voluntary counseling and testing (VCT).

In order to avoid selection biases 20 , serological status was not part of the questions asked.

\section{Statistical analysis}

Data analysis consisted of a descriptive analysis of the variables: mean and standard deviation for continuous variables, and frequencies and percentages for discrete variables. The significance level was set at alpha $=5 \%$. Bivariate and multivariate logistic regressions were performed and odds ratios were used to identify predictive factors for having ever tested for HIV.

Variables with a $\mathrm{p}<0.10$ in bivariate analyses were included in a stepwise model to select variables and obtain the final model. The goodness of fit test was used to quantify the model's fit to the data 21. Data was analyzed using Stata 10 (Stata Corp., College Station, USA).

\section{Ethical considerations}

The project was approved by the trans-border committee, a binational multidisciplinary committee, and by the Comité Consultatif sur le Traitement de l'Information en Matière de Recherche dans le Domaine de la Santé (CCTIRS; n. 09.106). All participants gave informed consent.

\section{Results}

Thirty-one percent of sex workers had never had an HIV test. Table 1 describes sociodemographic characteristics and characteristics of HIV testing among sex workers along the border.

HIV testing along the border mostly relies on rapid testing on the Brazilian side. In SaintGeorges-de-l'Oyapock, it relies mostly on ELISA tests performed in Cayenne. There is no laboratory either in Saint-Georges-de-l'Oyapock or in Oiapoque. When a patient is tested positive, a second sample is usually sent to Cayenne (3 hours away) for confirmation using Western Blot, or, on the Brazilian side, the patient is sent to Macapá which is 8 hours away by four wheel drive. The present study did not involve testing.

Thirty-eight percent of sex workers could not evaluate their risk of HIV, nearly a quarter thought they had a high risk (21.1\%) and $17.8 \%$ thought they had no risk or a low risk of HIV. Those who thought they had a high risk thought so because they had had unprotected sex and also often because they had a large number of partners. Twenty-six percent of sex workers did not know where to get an HIV test. Twelve percent of the sex workers thought that HIV-infected persons should be separated from the rest of society. Nearly $58 \%$ of surveyed sex workers had previously worked on a gold mining site, with this proportion increasing to $65 \%$ for sex workers in Oiapoque. Thirtytwo percent lived in a rented home and $18 \%$ lived where they worked, often night clubs or hotels. Seventy-five percent of the sex workers did not live in Oiapoque permanently and were in transit there. Table 2 describes the factors associated with having previously had an HIV test. Female sex workers who did not know where to take the HIV test, those that felt at risk or did not perceive their own risk, along with those who were older (> 30 years), and lived in Oiapoque were found to be less likely to have taken an HIV test.

\section{Discussion}

Although sex work is presumed to be a major driver of the epidemic on the Oyapock basin, only $62 \%$ of sex workers there had ever taken an HIV test. Moreover, most of those who had done a test had only done one test in their life, often recently on their own initiative because they wanted to know. Sex workers over 30 years of age were notably less likely to have done an HIV test. However during the survey, the sex workers were quite favourable to the prospect of getting an HIV test. It is noteworthy that none of the sex workers said that an NGO advised them to take an HIV test. Specific interventions by local NGOs could encourage and guide sex workers to carry out an HIV test.

Given the hidden nature of this population, snowball sampling, a non-probabilistic method, was used. For logistical reasons, Respondent Driven Sampling, the most recently used method applied to these populations could not be performed. The major drawback of snowball sampling is sampling bias ${ }^{18}$. So, in order to minimize the risks of non-representativeness of the sample, the study was conducted among heterogeneous 
Table 1

Sociodemographic and HIV testing characteristics among sex workers on the border between French Guiana and Brazil.

\begin{tabular}{|c|c|c|c|c|c|c|}
\hline & \multicolumn{2}{|c|}{ Total } & \multicolumn{2}{|c|}{ Saint Georges de l'Oyapock (French Guiana) } & \multicolumn{2}{|c|}{ Oiapoque (Brazil) } \\
\hline & $\mathrm{n}$ & $\%$ & $\mathbf{n}$ & $\%$ & $\mathrm{n}$ & $\%$ \\
\hline \multicolumn{7}{|l|}{ Age } \\
\hline Mean $(\mathrm{Cl})$ & \multicolumn{2}{|c|}{$27.5( \pm 6.6)$} & \multicolumn{2}{|c|}{$30.0( \pm 6.1)$} & \multicolumn{2}{|c|}{$27.5( \pm 6.7)$} \\
\hline Range & \multicolumn{2}{|c|}{$18-57$} & \multicolumn{2}{|c|}{$18-44$} & \multicolumn{2}{|c|}{$18-57$} \\
\hline \multicolumn{7}{|l|}{ Number of children cared for } \\
\hline Mean $(\mathrm{Cl})$ & \multicolumn{2}{|c|}{$2.19( \pm 1.31)$} & \multicolumn{2}{|c|}{$2.28( \pm 1.26)$} & \multicolumn{2}{|c|}{$2.07( \pm 1.34)$} \\
\hline Range & \multicolumn{2}{|c|}{$0-8$} & \multicolumn{2}{|c|}{$0-6$} & \multicolumn{2}{|c|}{$0-8$} \\
\hline \multicolumn{7}{|l|}{ School level } \\
\hline Incomplete primary & 102 & 51.8 & 0 & 0.0 & 102 & 61.8 \\
\hline Primary & 41 & 20.8 & 16 & 50.0 & 25 & 15.2 \\
\hline Secondary & 50 & 25.4 & 14 & 43.8 & 36 & 21.8 \\
\hline Higher education & 4 & 2.0 & 2 & 6.3 & 2 & 1.2 \\
\hline Total & 197 & 100.0 & 32 & 100.0 & 165 & 100.0 \\
\hline \multicolumn{7}{|l|}{ Lives in a couple } \\
\hline Yes & 40 & 21.6 & 13 & 38.2 & 27 & 17.9 \\
\hline No & 145 & 78.4 & 21 & 61.8 & 124 & 82.1 \\
\hline Total & 185 & 100.0 & 34 & 100.0 & 151 & 100.0 \\
\hline \multicolumn{7}{|l|}{ Have you ever had an HIV test? } \\
\hline Yes & 132 & 62.0 & 28 & 80.0 & 104 & 58.4 \\
\hline No & 67 & 31.5 & 2 & 5.7 & 65 & 36.5 \\
\hline Do not know & 7 & 3.3 & 0 & 0.0 & 7 & 3.9 \\
\hline No response & 7 & 3.3 & 5 & 14.3 & 2 & 1.1 \\
\hline Total & 213 & 100.0 & 35 & 100.0 & 178 & 100.0 \\
\hline \multicolumn{7}{|l|}{ Did you do it on your own initiative? } \\
\hline Own initiative & 100 & 75.8 & 23 & 82.1 & 77 & 74.0 \\
\hline Asked by someone else & 31 & 23.5 & 5 & 17.9 & 26 & 25.0 \\
\hline No response & 1 & 0.8 & 0 & 0.0 & 1 & 1.0 \\
\hline Total & 132 & 100.0 & 28 & 100.0 & 104 & 100.0 \\
\hline \multicolumn{7}{|l|}{ Why did you test? } \\
\hline Had sex without condom & 10 & 7.6 & 4 & 14.3 & 6 & 5.8 \\
\hline To know my status & 92 & 69.7 & 17 & 60.7 & 75 & 75.1 \\
\hline Shared a syringe & 0 & 0.0 & 0 & 0.0 & 0 & 0.0 \\
\hline Ruptured condom during sex & 8 & 6.1 & 4 & 14.3 & 4 & 3.8 \\
\hline A doctor advised me to & 10 & 7.6 & 4 & 14.3 & 6 & 5.8 \\
\hline A partner advised me to & 9 & 6.8 & 0 & 0.0 & 9 & 8.6 \\
\hline An NGO advised me to & 0 & 0.0 & 0 & 0.0 & 0 & 0.0 \\
\hline A customer advised me to & 1 & 0.8 & 0 & 0.0 & 1 & 1.0 \\
\hline A friend advised me to & 3 & 2.3 & 1 & 3.6 & 2 & 1.9 \\
\hline Other & 3 & 2.3 & 0 & 0.0 & 3 & 2.9 \\
\hline Do not know & 2 & 1.5 & 1 & 3.6 & 1 & 1.0 \\
\hline No response & 8 & 6.1 & 1 & 3.6 & 7 & 6.7 \\
\hline Did you receive your result? & & & & & & \\
\hline Yes & 124 & 93.9 & 25 & 89.3 & 99 & 95.2 \\
\hline No & 5 & 3.8 & 1 & 3.6 & 4 & 3.8 \\
\hline No response & 3 & 2.3 & 2 & 7.1 & 1 & 1.0 \\
\hline Total & 132 & 100.0 & 28 & 100.0 & 104 & 100.0 \\
\hline
\end{tabular}


Table 1 (continued)

\begin{tabular}{|c|c|c|c|c|c|c|}
\hline & \multicolumn{2}{|c|}{ Total } & \multicolumn{2}{|c|}{ Saint Georges de I'Oyapock (French Guiana) } & \multicolumn{2}{|c|}{ Oiapoque (Brazil) } \\
\hline & $\mathbf{n}$ & $\%$ & $\mathbf{n}$ & $\%$ & $\mathbf{n}$ & $\%$ \\
\hline \multicolumn{7}{|c|}{ How many HIV tests have you done? } \\
\hline 1 & 76 & 57.6 & 3 & 10.7 & 73 & 70.2 \\
\hline 2 & 30 & 22.7 & 6 & 21.4 & 24 & 23.1 \\
\hline 3 or more & 21 & 15.9 & 15 & 53.6 & 6 & 5.8 \\
\hline No response & 5 & 3.8 & 4 & 14.3 & 1 & 1.0 \\
\hline Total & 132 & 100.0 & 28 & 100.0 & 104 & 100.0 \\
\hline \multicolumn{7}{|c|}{ When did you last test? (months ago) } \\
\hline $0-2$ & 4 & 3.0 & 3 & 10.7 & 1 & 1.0 \\
\hline $3-5$ & 17 & 12.9 & 2 & 7.1 & 15 & 14.4 \\
\hline $6-11$ & 65 & 49.2 & 10 & 35.7 & 55 & 52.9 \\
\hline 12 or longer & 33 & 25.0 & 5 & 17.9 & 28 & 26.9 \\
\hline Do not know & 8 & 6.1 & 6 & 21.4 & 2 & 1.9 \\
\hline No response & 5 & 3.8 & 2 & 7.1 & 3 & 2.9 \\
\hline Total & 132 & 100.0 & 28 & 100.0 & 104 & 100.0 \\
\hline
\end{tabular}

$\mathrm{Cl}$ : confidence interval; NGO: non-governmental organization.

Table 2

Predictive factors of having performed a free voluntary HIV test on the border between French Guiana and Brazilian ( $\mathrm{n}=194)$ : bivariate and multivariate analyses.

\begin{tabular}{|c|c|c|c|c|}
\hline & $\begin{array}{l}\text { Has already been tested for HIV } \\
\text { n/total (\%) }\end{array}$ & Crude OR $(95 \% \mathrm{Cl})$ & Adjusted OR (95\%Cl) & $\begin{array}{l}\text { Adjusted } \\
\text { p-value }\end{array}$ \\
\hline \multicolumn{5}{|c|}{ Knowledge of where to test } \\
\hline Yes & $111 / 143(77.6)$ & 1.00 & 1.00 & \\
\hline No & 20/51 (39.2) & $0.12(0.07-0.20)$ & $0.23(0.10-0.52)$ & 0.000 \\
\hline \multicolumn{5}{|l|}{ Perceived risk of HIV } \\
\hline Feels at risk & $28 / 43(65.1)$ & $0.93(0.46-1.90)$ & $0.26(0.07-0.93)$ & 0.039 \\
\hline Does not feel at risk & $29 / 35(82.8)$ & 1.00 & 1.00 & \\
\hline Does not know & $35 / 77(45.4)$ & $0.21(0.11-0.40)$ & $0.33(0.11-0.99)$ & 0.049 \\
\hline No response & $40 / 44(90.9)$ & $6.85(2.33-20.10)$ & $3.46(0.79-15.08)$ & 0.099 \\
\hline \multicolumn{5}{|l|}{ Median age } \\
\hline Less than 30 & $94 / 129$ (72.9) & 1.00 & 1.00 & \\
\hline 30 or more & $38 / 70(54.3)$ & $1.40(0.91-2.15)$ & $0.28(0.12-0.63)$ & 0.002 \\
\hline \multicolumn{5}{|l|}{ Lives in Oiapoque } \\
\hline Yes & $104 / 169(61.5)$ & $0.11(0.03-0.49)$ & $0.05(0.01-0.28)$ & 0.001 \\
\hline No & $28 / 30(93.3)$ & 1.00 & 1.00 & \\
\hline
\end{tabular}

95\% $\mathrm{Cl}$ : 95\% confidence interval; OR: odds ratio.

networks (locations, and population profile) and using diverse surveyor profiles and seed persons used to start the snowball, used successfully in a previous study with another key population 22 . However, the results cannot be formally extrapolated to the entire population of female sex workers on the border. As with any observational study based on declarative data, results may have been biased by memory lapses or socially desirable responses 23 . The sample sizes were quite small and very different between the French and the Brazilian sides, reflecting the importance of the local demographics and the importance of the sex trade in Oiapoque. However, this was the first quantitative study among female sex workers on the French Guiana and Brazilian border 
and it highlights some important points about HIV and sex work in this area. It is also presumably recruited a majority of the female sex workers present at this time given the small overall population size.

Sex work was very different between SaintGeorges-de-l'Oyapock and Oiapoque, with mostly occasional and circumstantial sex work carried out at home on the French side, whereas on the Brazilian side sex work was more organized in dedicated venues (nightclubs, hotels...) and had strong connections with illegal gold mining ${ }^{3}$.

Populations engaging in gold mining established their base in Oiapoque. The city was the point of departure and return, in which the logistical aspects of gold mining are organized. Numerous women came from Northern Brazil to work as sex workers on gold mining sites. They were often only in transit for short stays in Oiapoque ${ }^{3}$. This partly explains why living in Oiapoque was associated with a greater likelihood of not having ever done an HIV test. Sex workers did not stop long in the city and mostly stayed where they worked and were presumably there to make money, without considering getting tested. Moreover, it is important to underline that Oiapoque has a poor health and social services infrastructure 24 and a positive test would have implied the need to go to Macapá and thus make it more difficult to reach the mining sites.

Not knowing where to get tested was linked to not having done a test but the presumed causal link could go both ways. Although $75 \%$ of sex workers knew where to get tested, only two thirds had actually done an HIV test. The lack of structures and personnel, and perhaps the fear of lack of confidentiality in small towns where HIV and sex work are stigmatized could be explanations for this low proportion of sex workers having tested for HIV 2 . Furthermore, testing rates could be impacted by the fact that rapid HIV tests were used in Oiapoque and HIV ELISA tests in SaintGeorges-de-l'Oyapock 24.

In the literature, the perception of being at risk for HIV can be associated with both increased HIV testing behavior and testing avoidance, but reports more often describe increased testing behavior 25,26 .

In our sample, nearly $60 \%$ thought they had a high risk of HIV or could not estimate their risk of getting HIV. This was associated with a lower likelihood of having done an HIV test, perhaps to avoid the negative consequences of a positive test $25,27,28,29$.

Prostitution in this border area has the particularity of being connected with illegal gold mining activities. Although it is lucrative, the working conditions on the mining sites are harsh. Access to condoms is complicated and women are very exposed to violence in remote sites.

The necessity to promote HIV testing on both sides of the border makes sense, because sex workers and clients are mobile on this border and may represent one of the principal drivers of the epidemic ${ }^{2}$. However, the health issues of gold miners were clearly neglected for a long time, presumably because authorities were reluctant to channel precious health resources towards these unwanted populations. However, a Brazilian French cooperation program has recently been implemented to promote prevention and testing activities along the border. But for the moment there has not been a specific program for sex workers who, because of their important turnover, require continuous targeted prevention and testing services. In Oiapoque as in Saint-Georges-de-l'Oyapock, just one NGO is responsible for HIV prevention activities in the general population. The apparent lack of mobility of sex workers outside their work place suggests that NGOs could have an important role in inciting them to get tested. Involving the owners and managers of the venues where sex work takes place, and involving the gold miners in transit for illegal sites in French Guiana also seems important to limit the propagation of the virus in the region. In Corumba, located in central-western Brazil, a collaboration between researchers, activists, health workers and government officials (both from Corumba and abroad) resulted in an intervention-research program to increase access to quality STI/HIV services for sex workers and create a more conductive environment in which sex workers could address mutual goals 24 . This example does offer hope for the effectiveness of similar efforts on the border 24 .

Finally, HIV testing implies HIV treatment facilities which are not present at the moment in Oiapoque where patients must make a 20 hour round trip on a difficult Amazonian road to collect their treatment in Macapá. This also could explain why female sex workers did not take the test. Plans to build and staff an HIV treatment center are underway and will hopefully rapidly allow on-site treatment for those testing positive.

The border between French Guiana and Brazil is a potential hotspot for HIV transmission. The main objective of this paper was to describe HIV testing among female sex workers. The results show high risks and low testing rates that strongly underline the need to focus efforts on this vulnerable group to effectively fight against the HIV epidemic in the area. 


\section{Resumen}

La frontera entre la Guyana Francesa y Brasil es un lugar de intercambio económico, cultural y sexual. En esta zona, donde se desarrolla sobre todo el turismo sexual, las trabajadoras del sexo son una población de alto riesgo de VIH. La prueba del VIH parece ser un elemento en la lucha de esta epidemia. Además, la prueba inmediata del VIH permite el acceso a los tratamientos y la prevención. Se realizó una Encuesta de Conocimientos, Actitudes y Prácticas sobre el VIH/ SIDA en 2011 entre las trabajadoras de sexo, trabajando en la frontera entre la Guyana Francesa y Brasil. Se entrevistaron a un total de 213 trabajadoras del sexo. Un tercio (31,5\%) de las entrevistadas nunca se había hecho la prueba del VIH. Los factores asociados con no haberse hecho la prueba del VIH son la ausencia de conocimientos sobre los lugares, donde se realiza la prueba del VIH, tener 30 años o más, sentirse en riesgo de VIH, no evalúan su propio riesgo frente al VIH y viviendo en el Oiapoque. Estos resultados muestran claramente que las intervenciones específicas necesitan incentivos para estimular el uso regularmente de la prueba del VIH.

Trabajadores Sexuales; Areas Fronterizas; VIH

\section{Contributors}

All authors contributed equally for the production of the paper.

\section{Acknowledgments}

The present study was jointly funded by the Agence Nationale de la Recherche sur le SIDA et les Hépatites virales (ANRS) and the European Union (FEDER). We would like to thank Joaquim Marques and Rosângela Evangelista, field coordinators, Mélina Bailleux and Carlos Wandescheer, coordinators of the cooperation program, the project team and all the participants in the study.

\section{References}

1. Bourdier F. L'avancée du sida dans les zones frontalières guyano-brésiliennes. Hommes \& Migrations 2005; (1256):116-29.

2. Guillemaut F, Schutz Samson M. Travail du sexe et mobilité en Guyane, des défis pour la lutte contre le VIH/Sida. Cayenne: Ministère du Travail, de l'Emploi et de la Santé; 2011.

3. Díaz J. A AIDS nas fronteiras do Brasil: diagnóstico estratégico da situação da epidemia deAIDS e doenças sexualmente transmissíveis nas fronteiras do Brasil. Brasília: Ministério da Saúde; 2003. (Coleção DST/AIDS - Série Estudos, Pesquisas e Avaliação).
4. Pascom ARP, Arruda M, Simão MBG. Pesquisa de conhecimentos, atitudes e práticas dapopulação brasileira de 15 a 64 anos 2008. Brasília: Ministério da Saúde; 2011.

5. Halfen S, Lydié N, Esvan M, Diter K. Les connaissances, attitudes, croyances et comportements face au VIH/Sida et à d'autres risques sexuels aux Antilles et en Guyane en 2011-12: principaux résultats. Paris: Observatoire Régional de Santé Île-de-France/Institut National de Prévention et d'Éducation pour la Santé/Agence Nationale de Recherches sur le Sida et les Hépatites Virales; 2013. 
6. Ministério da Saúde. Boletim Epidemiológico HIV/AIDS 2013; ano II, no 1.

7. Fonseca MGP, Bastos FI. Twenty-five years of the AIDS epidemic in Brazil: principal epidemiological findings, 1980-2005. Cad Saúde Pública 2007; 23 Suppl 3:S333-43.

8. Nacher M, Vantilcke V, Parriault M, Van Melle A, Hanf M, Labadie G, et al. What is driving the HIV epidemic in French Guiana? Int J STD AIDS 2010; 21:359-61.

9. Wilson D, Halperin DT. "Know your epidemic, know your response”: a useful approach, if we get it right. Lancet 2008; 372:423-6.

10. Bourdier F. Migration et sida en Amazonie française et brésilienne. Matoury: Ibis Rouge Editions; 2004.

11. Rodrigues-Júnior AL, Castilho EA. AIDS and transmissible opportunistic diseases in the Brazilian border area. Rev Soc Bras Med Trop 2010; 43:542-7.

12. Institut d'Emission des Départements d'OutreMer. Rapport annuel 2012. Cayenne: Institut d'Emission des Départements d'Outre-Mer; 2013.

13. Ministério da Saúde. Boletim Epidemiológico AIDS/DST 2010; ano VII, no 1.

14. World Health Organization. Surveillance de deuxième génération du VIH: les dix prochaines années. Report. Geneva: World Health Organization; 2000.

15. Sherr L, Lopman B, Kakowa M, Dube S, Chawira G, Nyamukapa C, et al. Voluntary counselling and testing: uptake, impact on sexual behaviour, and HIV incidence in a rural Zimbabwean cohort. AIDS 2007; 21:851-60.

16. Girardi E, Aloisi MS, Arici C, Pezzotti P, Serraino D, Balzano R, et al. Delayed presentation and late testing for HIV: demographic and behavioral risk factors in a multicenter study in Italy. J Acquir Immune Defic Syndr 2004; 36:951-9.

17. Hanf M, Bousser V, Parriault MC, Van-Melle A, Nouvellet M-L, Adriouch L, et al. Knowledge of free voluntary HIV testing centres and willingness to do a test among migrants in Cayenne, French Guiana. AIDS Care 2011; 23:476-85.

18. Magnani R, Sabin K, Saidel T, Heckathorn D. Review of sampling hard-to-reach and hidden populations for HIV surveillance. AIDS 2005; 19:S67-72.

19. Sadler GR, Lee HC, Lim RSH, Fullerton J. Recruitment of hard to reach population subgroups via adaptations of the snowball sampling strategy. Nurs Health Sci 2010; 12:369-74.
20. Amon J, Brown T, Hogle J, MacNeil J, Magnanl R, Mills S, et al. Behavioral surveillance surveys: guidelines for repeated behavioral surveys in populations at risk of HIV. Arlington: Family Health International; 2009.

21. Hosmer DW, Lemesbow S. Goodness of fit tests for the multiple logistic regression model. Commun Stat Theory Methods 1980; 9:1043-69.

22. Kerr-Pontes LR, Gondim R, Mota RS, Martins TA, Wypij D. Self-reported sexual behaviour and HIV risk taking among men who have sex with men in Fortaleza, Brazil. AIDS 1999; 13:709-17.

23. Cobat A, Halfen S, Grémy I. Déterminants de l'utilisation du préservatif et multipartenariat hétérosexuel aux Antilles et en Guyane françaises. Rev Epidemiol Sante Publique 2008; 56:143-57.

24. Lippman SA, Kerrigan D, Chinaglia M, Díaz J. Chaos, co-existence, and the potential for collective action: HIV-related vulnerability in Brazil's international borders. Soc Sci Med 2007; 64:2464-75.

25. Wang Y, Li B, Pan J, Sengupta S, Emrick CB, Cohen MS, et al. Factors associated with utilization of a free HIV VCT clinic by female sex workers in Jinan City, Northern China. AIDS Behav 2011; 15:702-10.

26. Irwin KL, Valdiserri RO, Holmberg SD. The acceptability of voluntary HIV antibody testing in the United States: a decade of lessons learned. AIDS 1996 10:1707-17.

27. Temmerman M, Ndinya-Achola J, Ambani J, Piot P. The right not to know HIV-test results. Lancet 1995; 345:969-70.

28. Wang Y, Li B, Zheng J, Sengupta S, Emrick CB, Cohen MS, et al. Factors related to female sex workers' willingness to utilize VCT service: a qualitative study in Jinan city, northern China. AIDS Behav 2009; 13:866-72.

29. Allen CF, Edwards M, Williamson LM, KitsonPiggott W, Wagner H-U, Camara B, et al. Sexually transmitted infection service use and risk factors for HIV infection among female sex workers in Georgetown, Guyana. J Acquir Immune Defic Syndr 2006; 43:96-101.

Submitted on 12/Sep/2014

Final version resubmitted on $02 / \mathrm{Jan} / 2015$

Approved on 02/Mar/2015 